DEIFGA LATA

Jurnal Ilmu Hukum

FAKULTAS HUKUM UMSU

\title{
KEBIJAKAN PENGELOLAAN LINGKUNGAN HIDUP DI ERA OTONOMI DAERAH
}

\author{
Erwin Hidayah Hasibuan \\ Fakultas Hukum Universitas Islam Sumatera Utara \\ Jl. Sisingmangaraja, Medan-Sumatera Utara \\ Email: erwinhsb64@gmail.com
}

\begin{abstract}
Abstrak
Pemerintah daerah harus berusaha mengembangkan potensi sumber daya alam yang ada hal ini untuk mendukung biaya pembangunan berkelanjutan. Secara formal ada 5 (lima) prinsip utama pembangunan berkelanjutan, yaitu prinsip keadilan antargenerasi, prinsip keadilan dalam satu generasi, prinsip pencegahan dini, prinsip perlindungan keanekaragaman hayati dan prinsip internalisasi biaya lingkungan. Terkait dengan prinsip internalisasi biaya lingkungan, pemerintah daerah ingin memaksakan pada pengusaha untuk mencari pendanaan internal dari setiap pengeluaran yang berdampak pada lingkungan. Oleh karena itu penerapan prinsip internalisasi biaya lingkungan dapat diartikan sebagai upaya memperhitungkan biayabiaya yang harus ditanggung oleh pelaku kegiatan ekonomi akibat munculnya kerugian lingkungan. Prinsip internalisasi biaya lingkungan mendasari konten pembangunan berkelanjutan, dan pada dasarnya bertujuan untuk membangkitkan kesadaran hukum para pelaku ekonomi untuk menjadi lebih kritis dalam menghitung dampak yang timbul dari kegiatan ekonomi mereka, dan dalam perspektif hukum, prinsip pembayaran pencemar harus dinormalisasi melalui pengaturan yang jelas, karena ini merupakan mandat dari Pasal 42 jo. Pasal 43 Undang-Undang Nomor 32 Tahun 2009 tentang Perlindungan dan Pengelolaan Lingkungan.
\end{abstract}

\section{Kata Kunci: Kebijakan, Lingkungan, Otonomi, Daerah}

\section{Abstract}

Local governments must try to develop the potential of existing natural resources, to support the costs of sustainable development, and formally there are 5 (five) main principles of sustainable development, namely; the principle of intergenerational justice, the principle of justice in one generation, the principle of early prevention, principles of biodiversity protection and the principle of internalizing environmental costs. Related to the principle of internalizing environmental costs, the local government wants to impose on employers to seek internal funding from any expenditure that has an impact on the environment. Therefore the application of the principle of internalization of environmental costs can be interpreted as an effort to take into account the costs that must be borne by economic activity players due to the emergence of environmental losses. The principle of internalization of environmental costs underlies the content of sustainable development, and in essence aims to arouse legal awareness of economic actors to be more critical in calculating the impacts arising from their economic activities, and in the legal perspective, the principle of polluter pay must be normalized through clear arrangements, because this is a mandate of Article 42 jo. Article 43 of Law Number 32 of 2009 concerning Protection and Management of the Environment.

Keywords: Policy, Environment, Goverment, Local 
DEIfGA IATA

Jurnal Ilmu Hukum

FAKULTAS HUKUM UMSU
Kebijkan Pengelolaan Lingkungan...(Erwin Hidayah Hasibuan)

Volume 3 Nomor 1, Januari-Juni 2018, 1-16

DOI: $\underline{\text { https://doi.org/10.30596/delegalata.v3i1.2753 }}$

\section{PENDAHULUAN}

Hakikat otonomi daerah yang ingin dibangun merupakan upaya untuk mendekatkan sistem pengelolaan sumber alam pada masyarakat di daerah, sehingga masyarakat yang bersangkutan dapat merasakan manfaat ekonomi dari eskploitasi sumber daya alam yang di daerahnya. Berbeda dengan pengalaman dari penguasaan sumber daya alam yang sentralistik di masa lalu, yang telah memberikan pelajaran berharga bagi pemerintah yang lebih banyak berpihak pada pemilik modal yang besar dan investor-investor baik dari dalam maupun luar negeri dengan menggunakan teknologi maju, justru menimbulkan kerusakan dan kehancuran lingkungan yang tidak terkendali dan konflik pada tataran masyarakat.

Secara konseptual subtansansi perundang-undangan yang berkaitan dengan hubungan hukum penguasaan sumber daya alam, tidak sesuai lagi dengan tujuan awalnya, karena ketentuan yang terdapat di dalamnya telah memberikan kekuasaan yang sangat besar kepada pemerintah daerah untuk mengatur dan mengurus segala sesuatu yang berkaitan dengaan sumber daya alam. Kekuasaan yang dimiliki daerah lambat laun mengeser hak-hak dan keberadaan masyarakat lokal. Kepentingan pemodal selalu lebih didahulukan, sehingga kepentingan rakyat atau masyarakat sekitar sumber daya alam terabaikan, padahal seharusnya pemerintah berpedoman pada Pasal 33 Ayat 3 Undang-undang Dasar Negara Republik Indonesia 1945 yang merupakan sumber hukum tertinggi untuk melakukan pengelolaan dan pengusahaan terhadap sumber daya alam (lingkungan hidup) di Indonesia.

Berbagai pengalaman selama ini menunjukkan bahwa pembangunan yang berorientasi pada aspek ekonomi tanpa pendekatan pemanfaatan sumberdaya yang berkelanjutan yang meliputi aspek pelestarian, kesejahteraan dan sosial ternyata hanya memberikan manfaat dalam jangka pendek. Pesatnya peningkatan per- tumbuhan populasi, teknologi dan di sisi lain semakin terbatasnya sumber daya alam dan rendahnya mutu lingkungan, menuntut adanya pola pembangunan yang terencana dengan baik, realistik dan strategik dan bernuansa lingkungan yang dalam jangka panjang dapat menjamin pemanfaatan sumber daya alam secara berkelanjutan.

Di dalam konteks otonomi daerah, maka pemerintah daerah seharusnya berusaha semaksimal mungkin untuk mengembangkan potensi yang ada guna menunjang biaya pembangunan berkelanjutan (sustainable development), karena pembangunan pada dasarnya merupakan rangkaian usaha terencana yang dilakukan secara sadar oleh suatu masyarakat dan bangsa bersama pemerintah untuk mengubah suatu keadaan yang kurang baik menjadi lebih baik, dengan cara melakukan proses pengolahan sumber daya alam dan sumber daya manusia dengan memanfaatkan teknologi untuk memenuhi masyarakat yang semakin kompleks dan terus berkembang yang disebabkan oleh laju pertambahan penduduk. Pembangunan akan membawa dampak negatif jika tidak ditata dengan baik sejak dini, yaitu dengan melaksanakan konsep pembangunan berkelanjutan yang berwawasan lingkungan hidup.

Melihat kecenderungan perkembangan dan tantangan pembangunan pada masa yang akan datang, maka perlu diperhatikan agar pembangunan dilakukan dan dipersiapkan dengan baik, dan salah satu kebijakan yang dapat dioperasikan adalah dengan meningkatkan dan memantapkan peran pemerintah daerah sebagai fasilitator untuk mendorong peran swasta dan masyarakat dalam pembangunan, dan menciptakan iklim yang kondusif bagi peran serta masyarakat, sehingga mutu atau kualitas pengelolaan sumber daya alam dan lingkungan hidup 
DE IFGa Lata

Jurnal Ilmu Hukum

FAKULTAS HUKUM UMSU

dapat terjaga.

\section{METODE PENELITIAN}

Penulisan ini menggunakan metode penelitian hukum yuridis normatif (normatif research). yaitu penelitian hukum yang dilakukan dengan cara meneliti bahan pustaka atau data skunder (Seokanto dan Sri Muji, 2003, h. 15). Spesifikasi penelitian dalam penulisan ini berupa penelitian deskriptif analistis. Deskriptif adalah menunjukan komparasi atau hubungan seperangkat data dengan seperangkat data yang lain. dan maksudnya adalah untuk memberikan gambaran. menelaah. menjelaskan dan menganalisis (Soekanto, 1996, h. 63).

Sesuai jenis dan sifat penelitiannya. maka sumber data yang digunakan dalam penulisan ini adalah data skunder yang terdiri dari bahan hukum primer berupa; berupa; UndangUndang Dasar 1945, Undang-undang Nomor 32 Tahun 2004 tentang Pemerintahan Daerah. Bahan hukum sekunder terdiri dari buku-buku. jurnal ilmiah. makalah dan artikel ilmiah yang dapat memberi penjelasan tentang bahan hukum primer. Bahan hukum tersier berupa Kamus Besar Bahasa Indonesia (KBBI) dan lain sebagainya dalam menemukan defenisi dari istilahistilah dalam membahas tentang pengembalian barang bukti dalam tindak pidana perikanan.

Prosedur yang digunakan untuk mengumpulkan data dalam penilitian ini berupa dokumentasi yaitu pedoman yang digunakan berupa catatan atau kutipan. Analisa bahan hukum dilakukan dengan menggunakan metode analisa konten (centent analysis method) yang dilakukan dengan menguraikan materi peristiwa hukum atau produk hukum secara rinci guna memudahkan interpretasi dalam pembahasan (Marzuki, 2011: 171). Penelitian ini bertujuan untuk menemukan jawaban terkait dengan prinsip desentralisasi dalam konsep otonomi daerah dalam hal pengelolaan lingkungan hidup.

\section{PEMBAHASAN}

\section{Prinsip Desentralisasi dalam Konsep Otonomi Daerah}

Istilah otonomi berasal dari Bahasa Yunani, yang terdiri dari kata 'autos' berarti berdiri dan 'nomos' berarti undang-undang. Otonomi bermakna membuat perundang-undangan sendiri (zelfwetgeving), tetapi dalam perkembangannya, konsepsi otonomi daerah juga mencakup "zelfbestur" (pemerintahan sendiri). Van der Pot sebagaimana dikutip Laica Marzuki (2009, h. 83). memahami konsep otonomi daaerah sebagai "eigen huishouding" (menjalankan rumah tangga sendiri). Berdasarkan Pasal 1 angka 5 Undang-Undang Nomor 32 Tahun 2004 tentang Pemerintahan Daerah (disebutkan bahwa hubungan kewenangan antara pusat dan daerah dalam konsep otonomi bertalian dengan cara pembagian penyelenggaraan pemerintahan. Istilah otonomi daerah sacara yuridis diartikan sebagai hak, wewenang, dan kewajiban daerah otonom untuk mengatur dan mengurus sendiri urusan pemerintahan dan kepentingan masyarakat setempat sesuai dengan peraturan perundang-undangan).

Prinsip dasar otonomi daerah mencakup 4 (empat) pengertian, yaitu: seluas-luasnya, nyata, bertanggungjawab dan keserasian hubungan antar daerah. Hal ini diuraikan dalam Penjelasan Umum Undang-Undang Nomor 32 Tahun 2004 tentang Pemerintahan Daerah, sebagai berikut:

a. Prinsip otonomi seluas-luasnya, dalam arti daerah diberikan kewenangan mengurus dan mengatur semua urusan pemerintahan di luar yang menjadi urusan pemerintah yang ditetapkan dalam undang-undang dan daerah memiliki kewenangan membuat kebijakan daerah untuk memberi pelayanan, pening- katan peranserta, prakarsa, dan 
DE IFGa Lata

Jurnal Ilmu Hukum

FAKULTAS HUKUM UMSU

pemberdayaan masyarakat yang bertujuan pada peningkatan kesejahteraan rakyat

b. Prinsip otonomi nyata adalah suatu prinsip bahwa untuk menangani urusan pemerintahan dilaksanakan berdasarkan tugas, wewenang, dan kewajiban yang senyatanya telah ada dan berpotensi untuk tumbuh, hidup dan berkembang sesuai dengan potensi dan kekhasan daerah, sehingga isi dan jenis otonomi bagi setiap daerah tidak selalu sama dengan daerah lainnya

c. Prinsip otonomi yang bertanggungjawab, yaitu otonomi yang dalam penyelenggaraannya harus benar-benar sejalan dengan tujuan dan maksud pem- berian otonomi, yang pada dasarnya untuk memberdayakan daerah termasuk meningkatkan kesejahteraan rakyat yang merupakan bagian utama dari tujuan nasional, sehinga penyelenggaraan otonomi daerah harus selalu berorientasi pada peningkatan kesejahteraan masyarakat dengan selalu memperhatikan kepentingan dan aspirasi yang tumbuh dalam masyarakat; dan

d. Prinsip otonomi daerah harus menjamin keserasian hubungan antara daerah dengan daerah lainnya, artinya mampu membangun kerjasama antar daerah untuk meningkatkan kesejahteraan bersama dan mencegah ketimpangan antar daerah. Otonomi daerah juga harus mampu menjamin hubungan yang serasi antar daerah dengan pemerintah, artinya harus mampu memelihara dan menjaga keutuhan wilayah negara dan tetap tegaknya Negara Kesatuan Republik Indonesia dalam rangka mewujudkan tujuan negara.

Berdasarkan pembagian wewenang tugas dan tanggung jawab untuk mengatur dan mengurus urusan pemerintahan antara pusat dan daerah, menurut Ni'matul Huda (2007, h. 20-25), dikatakan bahwa sistem otonomi daerah dapat dibedakan menjadi:

a. Sistem rumah tangga formal

Pada sistem rumah tangga formal, pembagian wewenang, tugas dan tanggung jawab antara pusat dan daerah untuk mengatur dan mengurus urusan pemerintahan tertentu tidak ditetapkan secara rinci, urusan pemerintah pusat dan daerah tidak dibedakan, dan secara teoritis sistem ini memberikan keleluasaan kepada daerah untuk mengatur dan mengurus urusan rumah tangganya sendiri

b. Sistem rumah tangga materil

Pada sistem rumah tangga materil ini ada pembagian wewenang, tugas dan tanggung jawab yang rinci antara pusat dan daerah. Urusan pemerintahan yang masuk dalam sistem rumah tangga daerah diatur secara rinci, dan dalam sistem ini berpangkal pada pemikiran bahwa urusan-urusan pemerintahan itu dapat dipilah-pilah dalam satuan pemerintahan.

c. Sistem rumah tangga nyata (riil)

Pada sistem ini penyerahan urusan atau tugas dan kewenangan daerah didasarkan pada faktor yang nyata atau riil, sesuai dengan kebutuhan dan kemampuan yang nyata dari daerah maupun pemerintah pusat serta pertumbuhan kehidupan masyarakat yang terjadi

d. Sistem rumah tangga sisa (residu)

Pada sistem ini, secara umum telah ditentukan lebih dahulu tugas-tugas yang menjadi wewenang pemerintah pusat, sedangkan sisanya menjadi urusan rumah tangga daerah

e. Sistem rumah tangga nyata, dinamis dan bertanggungjawab

Prinsip ini merupakan salah satu variasi dari sistem otonomi nyata, dalam arti bahwa pemberian otonomi kepada daerah harus didasarkan pada faktor-faktor, perhitungan, dan tindakan atas kebijaksanaan yang benar-benar dapat men- jamin daerah yang bersangkutan secara nyata mampu mengurus rumah tangganya sendiri. 
DEIFGA LATA

Jurnal Ilmu Hukum

FAKULTAS HUKUM UMSU

Bertanggungjawab berarti pemberian otonomi itu harus benar-benar sejalan dengan tujuannya dan menjamin hubungan yang serasi antara pemerintah pusat dan daerah, sedangkan kata dinamis hanya penekanan saja.

Di dalam perspektif otonomi daerah, daerah otonom berwenang mengatur dan mengurus kepentingan masyarakatnya sendiri, dan urusan-urusan dimaksud pada awalnya merupakan sebagai urusan pemerintah pusat yang selanjutnya diserahkan kepada daerah menjadi urusan daerah yang sifatnya otonom, sehingga otonomi daerah sebenarnya bersumber dari desentralisasi. Otonomi daerah dan desentralisasi merupakan 2 (dua) istilah yang berbeda, karena otonomi daerah diartikan sebagai hak, kewenangan dan kewajiban yang dimiliki pemerintah daerah. Berdasarkan Pasal 21 Undang-Undang Nomor 32 Tahun 2004, ditegaskan bahwa dalam menyelenggarakan otonomi, daerah mempunyai hak: (1) mengatur dan mengurus sendiri urusan pemerintahannya; (2) memilih pimpinan daerah; (3) mengelola aparatur daerah; (4) mengelola kekayaan daerah; (5) memungut pajak daerah dan retribusi daerah; (6) mendapatkan bagi hasil dari pengelolaan sumber daya alam dan sumber daya lainnya yang berada di daerah; (7) mendapatkan sumber-sumber pendapatan lain yang sah; dan (8) mendapatkan hak lainnya yang diatur dalam peraturan perundang-undangan. Desentralisasi, diartikan sebagai pelimpahan (pendelegasian) kewenangannya, yaitu pelimpahan (pendelegasian) kewenangan dari pemerintah (pusat) kepada pemerintah daerah. Dalam Pasal 1 angka 7 UU No. 32 Tahun 2004, ditegaskan bahwa desentralisasi adalah penyerahan wewenang pemerintahan oleh Pemerintah kepada daerah otonom untuk mengatur dan mengurus urusan pemerintahan dalam sistem Negara Kesatuan Republik Indonesia.

Istilah otonomi daerah dan desentralisasi dalam konteks bahasan sistem penyelenggaraan pemerintahan atau ketatanegaraan sering digunakan secara campur aduk (interchangeably). Kedua istilah ini secara praktis dalam penyelenggaraan pemerintahan tidak dapat dipisahkan, sehingga tidak mungkin masalah otonomi daerah dibahas tanpa melihat konteksnya dengan konsep desentralisasi. Berbagai definisi tentang desentralisasi dan otonomi daerah telah banyak dikemukakan yang pada umumnya didasarkan kepada sudut pandang yang berbeda, sehingga sulit untuk diambil defenisi yang tepat.

Bryant dan White (1987), sebagaimana dikutip Yoyon Bahtiar Irianto (t.t.:3) berpendapat bahwa dalam kenyataannya ada 2 (dua) bentuk desentralisasi, yaitu: (1) bersifat administrasi; dan (2) bersifat politik. Dalam konteks administrasi, maka desentralisasi diartikan sebagai pendelegasian wewenang pelaksanaan yang diberikan kepada pejabat pusat ditingkat lokal. Para pejabat tersebut bekerja dalam batas-batas rencana dan sumber pembiayaan yang sudah ditentukan, tetapi juga memiliki keleluasaan, kewenangan, dan tanggung jawab tertentu dalam mengembangkan kebijaksanaan pemberian jasa dan pelayanan di tingkat lokal. Kewenangan itu bervariasi, mulai dari penetapan peraturan- peraturan yang sifatnya pro-forma. sampai kepada keputusan-keputusan yang lebih substantif.

Dalam konteks politik, desentralisasi diartikan sebagai wewenang pembuatan keputusan dan kontrol tertentu terhadap sumber-sumber daya yang diberikan kepada badan-badan pemerintah regional dan lokal. Bryant dan White lebih menekankan pada dampak atau konsekuensi penyerahan wewenang untuk mengambil keputusan dan kontrol oleh badanbadan otonom daerah yang menuju pemberdayaan (empowerment) kapasitas lokal. Lebih lanjut dijelaskan bahwa desentralisasi juga merupakan salah satu cara untuk mengembangkan fasilitas lokal. Kekuasaan dan pengaruh cenderung bertumpu pada sumber daya, jika suatu 
deIfGA LATA

Jurnal Ilmu Hukum

FAKULTAS HUKUM UMSU

badan lokal diserahi tanggung jawab dan sumber daya, kemampuannya untuk mengembangkan otoritasnya akan meningkat, tetapi jika pemerintah lokal semata- mata ditugaskan untuk mengikuti kebijakan nasional, para pemuka dan masyarakat akan mempunyai investasi kecil saja. Sebaliknya jika suatu unit lokal diberi kesempatan untuk meningkatkan kekuasaannya, maka kekuasaan pada tingkat nasional tidak dengan sendirinya akan menyusut. Pemerintah pusat akan memperoleh prospek dan kepercayaan karena menyerahkan proyek dan sumber daya akan meningkatkan pengaruh serta legitimasinya.

Koesoemahatmadja, berpandangan bahwa desentralisasi dapat diartikan sebagai pelimpahan kekuasaan pemerintahan dari pusat kepada daerah-daerah untuk mengurus rumah tangganya sendiri (daerah-daerah otonom). Desentralisasi adalah sistem mewujudkan asas demokrasi, yang dalam proses penyelenggaraan kekuasaan negara, yang terdiri dari 2 (dua) jenis, yaitu: (1) dekonsentrasi (dekonsentrasi) atau ambtelijke decentralisatie, adalah pelimpahan kekuasaan dari alat perlengkapan negara pelimpahan kekuasaan dari alat perlengkapan negara tingkat lebih atas kepada bawahannya guna melancarkan pelaksanaan tugas pemerintahan, dan di sini rakyat tidak diikutsertakan; dan (2) desentralisasi ketatanegaraan (staatskundige decentralisatie) atau desentralisasi politik adalah pelimpahan kekuasaan perundangan dan pemerintahan (relegende en bestuurende bevoegheid) kepada daerah-daerah otonom, dan keikutsertaan rakyat dalam desentralisasi politik terbatas melalui perwakilan (Koesoemahatmadja, 1979, h. 14).

Berbeda dengan pengertian desentralisasi, maka yang dimaksud dengan otonomi dapat bermakna kebebasan atau kemandirian (zelfstandigheid) tetapi bukan kemerdekaan (onafhankelijkheid). Dalam konsep otonomi terkandung 2 (dua) aspek utama, yaitu: (1) pemberian tugas dan kewenangan untuk menyelesaikan suatu urusan; dan (2) pemberian kepercayaan dan wewenang untuk memikirkan dan menetapkan sendiri cara-cara penyelesaian tugas tersebut. Dengan demikian, otonomi dapat diartikan sebagai kesempatan untuk meng- gunakan prakarsa sendiri atas segala macam nilai yang dikuasai untuk mengurus kepentingan umum (penduduk). Kebebasan yang terbatas atau kemandirian itu merupakan wujud pemberian kesempatan yang harus dipertanggungjawabkan (Ateng Syafrudin, 1983, h. 23).

Penyerahan wewenang pemerintahan oleh pemerintah pusat kepada daerah otonom bermakna peralihan kewenangan secara delegasi, lazim disebut delegation of authority. Dengan demikian, pemberi delegasi akan kehilangan kewenangan yang didelegasikan, semua beralih kepada penerima delegasi, maksudnya bahwa pemerintah pusat kehilangan kewenangan yang sudah dilegasikan dan beralih menjadi tanggung jawab daerah otonom, kecuali urusan pemerintahan yang oleh undang-undang dinyatakan sebagai urusan pemerintah pusat.

Perlu pula digarisbawahi bahwa antara pembagian kewenangan dengan pembagian urusan jelas terdapat perbedaan yang mendasar. Secara yuridis, yang diartikan dengan kewenangan adalah hak dan kekuasaan pemerintah untuk menentukan atau mengambil kebijakan dalam rangka penyelenggaraan peme- rintahan, sedangkan urusan pemerintahan adalah isi dari kewenangan itu sendiri. Dalam Undang-Undang Nomor 32 Tahun 2004 yang diatur adalah pembagian urusan pemerintahan yang dituangkan khusus untuk penyelenggaraan pemerintahan. Dengan demikian, titik penekanannya adalah pada pembagian urusan maka kewenangan daerah hanya sebatas urusan yang telah ditetapkan dalam peraturan 
DE IFGa Lata

Jurnal Ilmu Hukum

FAKULTAS HUKUM UMSU

perundang-undangan dan akan bertambah apabila ada penyerahan dari pemerintah pusat. Kewenangan daerah bertambah jika ada penyerahan urusan dari pemerintah pusat tetapi dalam Undang-Undang Nomor 32 Tahun 2004, desentralisasi dimaknai sebagai penyerahan wewenang, walaupun sesungguhnya hanya penyerahan urusan, dan atas urusan yang diserahkan kepada daerah itu diberikan rambu-rambu yang tidak mudah untuk dikelola daerah dengan leluasa sebagai urusan rumah tangga sendiri

Melalui desentralisasi, kesejahteraan masyarakat di daerah akan lebih cepat terwujud, karena pemerintah daerah akan lebih fleksibel bertindak dalam merespon perubahan lingkungan dan kebutuhan masyarakat di daerah. Selain itu, desentralisasi lebih melibatkan partisipasi aktif dalam pengambilan keputusan daripada harus menunggu keputusan dari pemerintah pusat, sehingga kehidupan demokrasi lebih terwujud, lebih memberi ruang untuk berkreasi dan berinovasi, dan menghasilkan semangat kerja, komitmen dan produktivitas yang lebih tinggi.

Sesuai dengan konsep-konsep dasar dari otonomi daerah yang dipaparkan di atas, maka dapat dikemukakan bahwa pelaksanaan otonomi daerah pada dasarnya ditujukan untuk meningkatkan pelayanan kepada masyarakat dengan mendekatkan antara pembuat kebijakan dengan masyarakat yang menerima kebijakan tersebut, sehingga kebijakan yang dikeluarkan benar-benar dapat menyentuh akar permasalahan dan sesuai dengan kebutuhan masyarakat. Melalui pelimpahan wewenang dari pemerintah pusat kepada pemerintah daerah diharapkan proses pengambilan keputusan untuk kepentingan masyarakat banyak, dapat melibatkan semua komponen yang ada dalam masyarakat bersangkutan dengan tetap memperhatikan ciri khas budaya dan lingkungan setempat.

Penyelenggaraan pemerintah daerah yang mengatur dan mengurus sendiri urusan pemerintahan untuk mempercepat terwujudnya kesejahteraaan masyarakat melalui peningkatan, pelayanan, pemberdayaan, dan peran serta masyarakat, serta peningkatan daya saing daerah, pada dasarnya merupakan realisasi dari ide desentralisasi. Orientasi otonomi sudah seharusnya diupayakan untuk memaksi- malkan fungsi pemerintahan yang dilakukan secepat, sedekat, dan setepat mungkin dengan kebutuhan masyarakat daerah setempat.

Pada hakikatnya, otonomi merupakan wujud nyata desentralisasi. Dalam bahasa yang sederhana otonomi adalah suatu keadaan yang tidak tergantung pada siapa pun. Dalam bahasa yang lebih politis, yaitu dalam konteks hubungan pusat- daerah, otonomi merupakan sebuah kewenangan yang dimiliki oleh daerah untuk mengatur sistem administrasi birokrasi, keuangan, kebijakan publik, dan hal-hal lain, dalam batasan-batasan yang telah ditetapkan dan disepakati bersama.

Penerapan desentralisasi dan otonomi daerah di Indonesia, sesuai dengan Bhineka Tunggal Ika kita, yang terdiri dari ribuan pulau, ratusan kultur dan subkultur yang menyebar di seluruh nusantara. Dengan berdasarkan pada variasi lokalitas yang sangat beragam itu, maka sangat tepat untuk menerapkan otonomi daerah. Hal ini akan memberi peluang seluas luasnya bagi tiap daerah untuk berkembang sesuai potensi alam dan sumber daya manusia yang ada di masing masing daerah dan kemudian akan menciptakan suasana kompetisi antar daerah dalam mewujudkan kesejahteraan bagi rakyatnya.

\section{Kebijakan Pengelolaan Lingkungan Hidup}

Penggunaan istilah pembangunan berkelanjutan (sustainable development) 
DE IFGa Lata

Jurnal Ilmu Hukum

FAKULTAS HUKUM UMSU

diperkenalkan pertama kali pada masa 1970-an dan menjadi istilah utama pada saat dan setelah terbentuknya World Commission on Environment and Development (WCED) 1987 atau lebih dikenal dengan Brundtland Commission. Komisi ini mendefinisikan pembangunan berkelanjutan sebagai pembangunan yang dapat memenuhi kebutuhan sekarang tanpa mengorbankan pemenuhan kebutuhan generasi masa depan (World Commission on Environment and Development [WCED], 1987: h. 43).

Di dalam World Summit Report 2005, dijelaskan bahwa pembangunan berkelanjutan haruslah didirikan di atas tiga pilar pokok, yaitu: ekonomi, sosial, dan lingkungan. Ketiganya dibentuk untuk dapat saling menopang antara satu dengan lainnya (Thomas A. Easton, 2008, h. 28-33), sehingga dapat dirumuskan bahwa pembangunan berkelanjutan tidak memfokuskan diri pada aspek pembangunan ekonomi dan sosial semata, tetapi harus berlandaskan pada perlindungan terhadap lingkungan, dan dalam pengembangan konsep pembangunan berkelanjutan juga termasuk pemenuhan kebutuhan dasar (basic needs), serta tersalurnya kesempatan untuk memberikan aspirasi kehidupan yang lebih baik.

Terkait dengan isu perubahan iklim, maka perlu juga diperhatikan hasil Konferensi Tingkat Tinggi (KTT) Pembangunan Berkelanjutan yang dilaksanakan di Johannesburg, Afrika Selatan pada tahun 2002, yang telah merumuskan asas-asas pembangunan berkelanjutan, yaitu: (1) keadilan antargenerasi (intergenerational equity), (2) keadilan dalam satu generasi (intragenerational equity), (3) prinsip pencegahan dini (precautionary principle), (4) perlindungan keanekaragaman hayati (conversation of biological diversity) dan (5) internalisasi biaya lingkungan (internalisation of environment cost and incentive mechanism). Salah satu hasil yang disepakati untuk menunjang pembangunan berkelanjutan yaitu dilakukannya suatu pendekatan yang terpadu, memperhatikan berbagai aspek bahaya (multihazard) dan inklusi untuk menangani kerentanan, penilaian resiko, dan penanggulangan bencana, termasuk pencegahan, mitigasi, kesiapan, tanggapan dan pemulihan yang merupakan unsur penting bagi dunia yang lebih aman di abad ke-21 (Supriadi, 2008, h. 104-107).

Prinsip-prinsip yang terkandung dalam konsep pembangunan ber- kelanjutan dikemukakan pula secara rinci dalam deklarasi dan perjanjian internasional yang dihasilkan melalui Konferensi PBB tentang Lingkungan dan Pembangunan (United Nations Conference on Environment and Development) di Rio de Janeiro pada tahun 1992. Dari berbagai dokumen yang telah dihasilkan pada konferensi itu, secara formal terdapat lima prinsip utama dari pembangunan berkelanjutan, yaitu:

a Prinsip keadilan antargenerasi (intergenerational equity principle); prinsip ini mengandung makna bahwa setiap generasi umat manusia di dunia memiliki hak untuk menerima dan menempati bumi bukan dalam kondisi yang buruk akibat perbuatan generasi sebelumnya

b. Prinsip keadilan dalam satu generasi (intergenerational equity principle); yaitu prinsip keadilan dalam satu generasi merupakan prinsip yang berbicara tentang keadilan di dalam sebuah generasi umat manusia, di mana beban dari permasalahan lingkungan harus dipikul bersama oleh masyarakat dalam satu generasi

c. Prinsip pencegahan dini (precautionary principle), yaitu prinsip pencegahan dini yang mengandung suatu pengertian bahwa apabila ada ancaman yang berat atau adanya ancaman kerusakan lingkungan yang tidak dapat dipulihkan serta ketiadaan temuan atau pembuktian ilmiah yang konsklusif dan pasti, tidak dapat dijadikan alasan untuk menunda upaya-upaya mencegah terjadinya kerusakan lingkungan 
DEIFGA LATA

Jurnal Ilmu Hukum

FAKULTAS HUKUM UMSU

d. Prinsip perlindungan keragaman hayati; maksudnya bahwa perlindungan keragaman hayati merupakan prasyarat dari berhasil tidaknya pelaksanaan prinsip keadilan antargenerasi, dan perlindungan keragaman hayati diperlukan demi pencegahan dini; dan Prinsip internalisasi biaya lingkungan, berarti kerusakan lingkungan dapat dilihat sebagai external cost (biaya eksternal) dari suatu kegiatan ekonomi yang diderita oleh pihak yang tidak terlibat dalam kegiatan ekonomi tersebut, dan oleh sebab itu kerusakan lingkungan merupakan external cost yang harus ditanggung kegiatan pelaku ekonomi, sehingga biaya kerusakan lingkungan harus diintegrasikan ke dalam proses pengambilan keputusan yang berkaitan dengan penggunaan sumber-sumber alam.

Kelima prinsip tersebut di atas dikenal sebagai prinsip pokok dari pem- bangunan berkelanjutan dan berwawasan lingkungan, yang kemudian dijadikan landasan hukum oleh sebagian besar peserta KTT Bumi 1992 lingkungan, baik tingkat global (sebagaimana tertuang dalam deklarasi dan dokumen-dokumen internasional yang dihasilkan melalui KTT Bumi 1992, maupun tingkat nasional sebagaimana tertuang dalam Undang-undang Nomor 32 Tahun 2009 tentang Perlindungan dan Pengelolaan Lingkungan Hidup (Undang-Undang Nomor 32 Tahun 2009). Diterbitkannya Undang-Undang Nomor 32 Tahun 2009 dengan mengadopsi prinsip-prinsip pembangunan berkelanjutan, telah menunjukkan adanya perhatian serius dari pemerintah untuk mengelola sumber daya lingkungan secara terencana dengan memperhatikan kepentingan masa depan dan masa sekarang, tetapi memperhati- kan kondisi umum yang ada, membuktikan bahwa konsep pembangunan berkelanjutan hanyalah dalam tataran kebijaksanaan. Dalam pengalaman praktik- nya, ternyata pengelolaan sumber daya alam (lingkungan) masih tidak terkendali, sehingga telah mengakibatkan kerusakan dan/atau pencemaran lingkungan. Hal ini terjadi karena luasnya ruang lingkup pembangunan daerah, terutama dalam rangka pelaksanaan otonomi daerah yang belum didukung kesiapan serta kemampuan sumber daya manusia dan aparatur pemerintah daerah yang memadai, baik secara kuantitas (jumlah), maupun secara kualitas (seperti keahlian manajerial), bahkan belum adanya perangkat peraturan bagi pengelolaan sumber daya alam di daerah.

Sehubungan dengan kondisi sebagaimana tersebut dipaparkan di atas, maka diperlukan adanya kebijakan pengelolaan lingkungan hidup yang didasarkan pada kebijakan dan program pembangunan nasional yang ditetapkan sesuai dengan amanat konstitusi berdasarkan visi bangsa Indonesia yang ingin dicapai yaitu terwujudnya masyarakat Indonesia yang damai demokratis, berkeadilan, berdaya saing, maju dan sejahtera, dalam wadah negara Kesatuan Republik Indonesia yang didukung manusia Indonesia yang sehat, mandiri, beriman, bertaqwa, berakhlak mulia, cinta tanah air, berkesadaran hukum dan lingkungan, menguasai ilmu pengetahuan dan teknologi, memiliki etos kerja yang tinggi serta disiplin. Kebijakan ini diperlukan untuk menyikapi penerapan otonomi daerah dalam konteks pengelolaan lingkungan hidup dan sumber daya alam baik, yang berada dalam batas administratif satu daerah otonom, maupun sumber daya alam yang berada dalam lintas batas administratif antar daerah.

Sejalan dengan semangat otonomi daerah, maka pendelegasian secara bertahap wewenang pemerintah pusat kepada pemerintah daerah dalam penge- lolaan lingkungan hidup dan sumber daya alam dimaksudkan untuk meningkatkan peranan masyarakat lokal dan tetap terjaganya kelestarian fungsi lingkungan. Otonomi daerah merupakan potensi utama dalam pengelolaan lingkungan hidup dengan lebih baik, dalam perwujudan pemerintahan yang baik, 
DE IFGa Lata

Jurnal Ilmu Hukum

FAKULTAS HUKUM UMSU
Kebijkan Pengelolaan Lingkungan...(Erwin Hidayah Hasibuan)

Volume 3 Nomor 1, Januari-Juni 2018, 1-16

DOI: $\underline{\text { https://doi.org/10.30596/delegalata.v3i1.2753 }}$

dan tuntutan kualitas sumber daya manusia dalam rangka implementasi otonomi daerah dalam pengelolaan lingkungan hidup. Kebijakan pengelolaan dan lingkungan hidup harus ditujukan untuk hal-hal sebagai berikut:

a. Mengupayakan pengelolaan melalui penerapan teknologi ramah lingkungan dengan memperhatikan daya dukung dan daya tampungnya;

b. Penegakan hukum secara adil dan konsisten untuk menghindari perusakan dan/atau pencemaran lingkungan hidup;

c. Pendelegasian kewenangan dan tanggung jawab kepada pemerintah daerah dalam pengelolaan lingkungan hidup secara bertahap;

d. Pemberdayaan masyarakat dan kekuatan ekonomi dalam pengelolaan sumber daya alam dan lingkungan hidup bagi peningkatan kesejahteraan lokal;

e. Penerapan secara efektif terhadap penggunaan indikator-indikator untuk mengetahui keberhasilan pengelolaan sumberdaya alam dan lingkungan hidup;

f. Pemeliharaan kawasan konservasi yang sudah ada dan menetapkan kawasan konservasi bagi di wilayah tertentu; dan

g. Pengikutsertaan masyarakat dalam rangka menanggulangi permasalahan lingkungan global.

Pemerintah daerah harus mampu menyusun rumusan kebijakan pengelolaan lingkungan hidup di daerah, dengan mengingat Pasal 17 ayat (1) Undang-Undang Nomor 32 Tahun 2004 yang menegaskan bahwa hubungan dalam bidang pemanfaatan sumber daya alam dan sumber daya lainnya antara pemerintah dan pemerintahan daerah, meliputi: (1) kewenangan, tanggung jawab, pemanfaatan, pemeliharaan, pengendalian dampak, budidaya, dan pelestarian; (2) bagi hasil atas pemanfaatan sumber daya alam dan sumber daya lainnya; dan (3) penyerasian lingkungan dari tata ruang serta rehabilitasi lahan. Selain itu dalam Pasal 17 ayat (2) Undang-Undang Nomor 32 Tahun 2004, ditentukan pula bahwa hubungan dalam bidang pemanfaatan sumber daya alam dan sumber daya lainnya antar pemerintahan daerah, meliputi: (1) pelaksanaan pemanfaatan sumber daya alam dan sumber daya lainnya yang menjadi kewenangan daerah; (2) kerja sama dan bagi hasil atas pemanfaatan sumber daya alam. Dan sumber daya lainnya antar pemerintahan daerah; dan (3) pengelolaan perizinan bersama dalam pemanfaatan sumber daya alam dan sumber daya lainnya.

Kebijakan pengelolaan lingkungan hidup di daerah ini harus disesuaikan dengan misi pembangunan nasional yang dituangkan dalam Lampiran Undang-Undang Nomor 17 Tahun 2007 tentang Rencana Pembangunan Jangka Panjang Nasional Tahun 2005-2025 (UndangUndang Nomor 17 Tahun 2007) yaitu untuk mewujudkan Indonesia asri dan lestari dengan memperbaiki pengelolaan pelaksanaan pem- bangunan yang dapat menjaga keseimbangan antara pemanfaatan, keberlanjutan, keberadaan, dan kegunaan sumber daya alam dan lingkungan hidup dengan tetap menjaga fungsi, daya dukung, dan kenyamanan dalam kehidupan pada masa kini dan masa depan, melalui pemanfaatan ruang yang serasi antara penggunaan untuk permukiman, kegiatan sosial ekonomi, dan upaya konservasi; meningkatkan pemanfaatan ekonomi sumber daya alam dan lingkungan yang berkesinambungan; memperbaiki pengelolaan sumber daya alam dan lingkungan hidup untuk mendukung kualitas kehidupan; memberikan keindahan dan kenyamanan kehidupan; serta meningkatkan pemeliharaan dan pemanfaatan keanekaragaman hayati sebagai modal dasar pembangunan. Sasaran yang hendak dicapai adalah terwujudnya Indonesia yang asri dan 
DE IFGa Lata

Jurnal Ilmu Hukum

FAKULTAS HUKUM UMSU
Kebijkan Pengelolaan Lingkungan...(Erwin Hidayah Hasibuan)

Volume 3 Nomor 1, Januari-Juni 2018, 1-16

DOI: $\underline{\text { https://doi.org/10.30596/delegalata.v3i1.2753 }}$

lestari ditandai oleh hal-hal berikut:

a. Membaiknya pengelolaan dan pendayagunaan sumber daya alam dan pelestarian fungsi lingkungan hidup yang dicerminkan oleh tetap terjaganya fungsi, daya dukung, dan kemampuan pemulihannya dalam mendukung kualitas kehidupan sosial dan ekonomi secara serasi, seimbang, dan lestari;

b. Terpeliharanya kekayaan keragaman jenis dan kekhasan sumber daya alam untuk mewujudkan nilai tambah, daya saing bangsa, modal pembangunan nasional; dan

c. Meningkatnya kesadaran, sikap mental, dan perilaku masyarakat dalam penge- lolaan sumber daya alam dan pelestarian fungsi lingkungan hidup untuk menjaga kenyamanan dan kualitas kehidupan.

Arah kebijakan pengelolaan lingkungan hidup di daerah, harus pula sesuai dengan arah kebijakan pembangunan nasional, yaitu:

a. Mendayagunakan sumber daya alam yang terbarukan:

Sumber daya alam terbarukan, baik di darat dan di laut, harus dikelola dan dimanfaatkan secara rasional, optimal, efisien, dan bertanggung jawab dengan mendayagunakan seluruh fungsi dan manfaat secara seimbang. Pengelolaan sumber daya alam terbarukan yang sudah berada dalam kondisi kritis diarahkan pada upaya untuk merehabilitasi dan memulihkan daya dukungnya yang selanjutnya diarahkan pada pemanfaatan jasa lingkungan sehingga tidak semakin merusak dan menghilangkan kemampuannya sebagai modal bagi pembangunan yang berkelanjutan. Hasil atau pendapatan yang berasal dari pemanfaatan sumber daya alam terbarukan diinvestasikan kembali guna menumbuhkembangkan upaya pemulihan, rehabilitasi, dan pencadangan untuk kepentingan generasi sekarang maupun generasi mendatang. Di samping itu, pemanfaatan sumber daya alam yang terbarukan akan diarahkan untuk memenuhi kebutuhan energi dalam negeri dengan memanfaatkan sumber daya berbasis kelautan dan hasil-hasil pertanian sebagai energi alternatif.

b. Mengelola sumber daya alam yang tidak terbarukan

Pengelolaan sumber daya alam tak terbarukan, seperti bahan tambang, mineral, dan sumber daya energi diarahkan untuk tidak dikonsumsi secara langsung, melainkan diperlakukan sebagai masukan, baik bahan baku maupun bahan bakar, untuk proses produksi yang dapat menghasilkan nilai tambah yang optimal di dalam negeri. Selain itu, sumber daya alam tak terbarukan pemanfaatannya harus seefisien mungkin dan menerapkan strategi mem- perbesar cadangan dan diarahkan untuk mendukung proses produksi di dalam negeri. Pemanfaatan sumber daya energi yang tidak terbarukan, seperti minyak dan gas bumi, terutama diarahkan untuk memenuhi kebutuhan energi yang terjangkau masyarakat di dalam negeri dan untuk mendukung industri berbasis hidrokarbon, seperti industri petrokimia, industri pupuk dalam mendukung sektor pertanian di dalam negeri. Keluarannya (output) diarahkan untuk dapat dijadikan sebagai modal kumulatif. Hasil atau pendapatan yang diperoleh dari kelompok sumber daya alam tersebut diarahkan untuk percepatan pertumbuhan ekonomi dengan diinvestasikan pada sektorsektor lain yang produktif, juga untuk upaya reklamasi, konservasi, dan memperkuat pendanaan dalam pencarian sumber-sumber energi alternatif yang menjadi jembatan dari energi fosil ke energi yang terbarukan, seperti energi yang memanfaatkan nuklir dan panas bumi dan atau bahan substitusi yang terbarukan dan atau bahan substitusi yang terbarukan 
DE IFGa Lata

Jurnal Ilmu Hukum

FAKULTAS HUKUM UMSU
Kebijkan Pengelolaan Lingkungan...(Erwin Hidayah Hasibuan)

Volume 3 Nomor 1, Januari-Juni 2018, 1-16 DOI: $\underline{\text { https://doi.org/10.30596/delegalata.v3i1.2753 }}$

seperti biomassa, biogas, mikrohidro, energi matahari, arus laut, panas bumi (geothermal) dan tenaga angin yang ramah lingkungan. Pengembangan sumber-sumber energi alternatif itu disesuaikan dengan kondisi masyarakat dengan tetap mempertimbangkan kelestarian lingkungan. Selain itu, pengembangan energi juga memper- timbangkan harga energi yang memperhitungkan biaya produksi, meng- internalisasikan biaya lingkungan, serta mempertimbangkan kemampuan ekonomi masyarakat. Dengan demikian, pembangunan energi terus diarahkan kepada keragaman energi dan konservasi energi dengan memerhatikan kelestarian fungsi lingkungan hidup. Pengembangan energi juga dilaksanakan dengan memerhatikan komposisi penggunaan energi (diversifikasi) yang optimal bagi setiap jenis energi.

c. Menjaga keamanan ketersediaan energi

Menjaga keamanan ketersediaan energi diarahkan untuk menyediakan energi dalam waktu yang terukur antara tingkat ketersediaan sumber-sumber energi dan tingkat kebutuhan masyarakat.

d. Menjaga dan melestarikan sumber daya air

Pengelolaan sumber daya air diarahkan untuk menjamin keberlanjutan daya dukungnya dengan menjaga kelestarian fungsi daerah tangkapan air dan keberadaan air tanah; mewujudkan keseimbangan antara pasokan dan kebutuhan melalui pendekatan demand management yang ditujukan untuk meningkatkan efektivitas dan efisiensi penggunaan dan konsumsi air dan pendekatan supply management yang ditujukan untuk meningkatan kapasitas dan keandalan pasokan air; serta memperkokoh kelembagaan sumber daya air untuk meningkatkan keterpaduan dan kualitas pelayanan terhadap masyarakat.

e. Mengembangkan potensi sumber daya kelautan

Arah pembangunan ke depan perlu memerhatikan pendayagunaan dan pengawasan wilayah laut yang sangat luas. Dengan cakupan dan prospek sumber daya kelautan yang sangat luas, arah pemanfaatannya harus dilakukan melalui pendekatan multisektor, integratif, dan komprehensif agar dapat meminimalkan konflik dan tetap menjaga kelestariannya. Selain itu, mengingat kompleksnya permasalahan dalam pengelolaan sumber daya laut, pesisir, dan pulau-pulau kecil, pendekatan keterpaduan dalam kebijakan dan perencanaan menjadi prasyarat utama dalam menjamin keberlanjutan proses ekonomi, sosial, dan lingkungan. Kebijakan dan pengelolaan pembangunan kelautan harus merupakan keterpaduan antara sektor lautan dan daratan serta menyatu dalam strategi pembangunan nasional sehingga kekuatan darat dan laut dapat dimanfaatkan secara optimal untuk kesejahteraan bangsa.

f. Meningkatkan nilai tambah atas pemanfaatan sumber daya alam tropis yang unik dan khas Diversifikasi produk dan inovasi pengolahan hasil sumber daya alam terus dikembangkan agar mampu menghasilkan barang dan jasa yang memiliki nilai tambah yang tinggi, termasuk untuk pengembangan mutu dan harga yang bersaing dalam merebut persaingan global. Arah ini harus menjadi acuan bagi pengembangan industri yang berbasis sumber daya alam selain tetap menekankan pada pemeliharaan sumber daya alam yang ada dan sekaligus meningkatkan kualitas dan kuantitasnya. Perhatian khusus diberikan kepada masyarakat lokal agar dapat memeroleh akses yang memadai dan menikmati hasil dari pemanfaatan sumber daya alam yang ada di wilayahnya. Dengan demikian, pembangunan pada masa datang tidak hanya berlandaskan pada peningkatan pertumbuhan ekonomi 
DE IFGa Lata

Jurnal Ilmu Hukum

FAKULTAS HUKUM UMSU
Kebijkan Pengelolaan Lingkungan...(Erwin Hidayah Hasibuan)

Volume 3 Nomor 1, Januari-Juni 2018, 1-16

DOI: $\underline{\text { https://doi.org/10.30596/delegalata.v3i1.2753 }}$

semata, melainkan juga keberpihakan kepada aspek sosial dan lingkungan.

g. Memerhatikan dan mengelola keragaman jenis sumber daya alam yang ada di setiap wilayah

Kebijakan pengembangan sumber daya alam yang khas pada setiap wilayah dilaksanakan untuk meningkatkan kesejahteraan masyarakat lokal, mengem- bangkan wilayah strategis dan cepat tumbuh, serta memperkuat kapasitas dan komitmen daerah untuk mendukung pembangunan yang berkelanjutan. Peningkatan partisipasi masyarakat akan pentingnya pemanfaatan sumber daya alam dan lingkungan hidup dilakukan oleh pemerintah pusat maupun pemerintah daerah antara lain melalui pemberdayaan terhadap berbagai institusi sosial dan ekonomi di tingkat lokal, serta pengakuan terhadap hak-hak adat dan ulayat atas sumber daya alam. Pengelolaan sumber daya alam di luar pulau Jawa, terutama di kawasan tertinggal diberikan perhatian khusus agar dapat dikembangkan potensinya untuk percepatan pembangunan wilayah, tetapi tetap mengedepankan aspek keberlanjutan bagi generasi mendatang.

h. Mitigasi bencana alam sesuai dengan kondisi geologi Indonesia:

Secara geografis Indonesia berada di wilayah pertemuan tiga lempeng tektonik. Kebijakan pembangunan berwawasan lingkungan memberikan ruang untuk mengembangkan kemampuan dan penerapan sistem deteksi dini serta sosialisasi dan diseminasi informasi secara dini terhadap ancaman kerawanan bencana alam kepada masyarakat. Untuk itu, perlu ditingkatkan identifikasi dan pemetaan daerah-daerah rawan bencana agar dapat diantisipasi secara dini. Hal itu dapat memberikan manfaat besar bagi masyarakat dan memberikan perlindungan terhadap manusia dan harta benda karena adanya perencanaan wilayah yang peduli/peka terhadap bencana alam.

i. Mengendalikan pencemaran dan kerusakan lingkungan:

Di dalam rangka meningkatkan kualitas lingkungan hidup yang baik perlu penerapan prinsip-prinsip pembangunan yang berkelanjutan secara konsisten di segala bidang. Pembangunan ekonomi diarahkan pada pemanfaatan jasa lingkungan yang ramah lingkungan sehingga tidak mempercepat terjadinya degradasi dan pencemaran lingkungan. Pemulihan dan rehabilitasi kondisi lingkungan hidup diprioritaskan pada upaya peningkatan daya dukung lingkungan dalam menunjang pembangunan berkelanjutan.

j. Meningkatkan kapasitas pengelolaan sumber daya alam dan lingkungan hidup Kebijakan pengelolaan sumber daya alam perlu didukung oleh peningkatan kelembagaan pengelola sumber daya alam dan lingkungan hidup; penegakan hukum lingkungan yang adil dan tegas serta sistem politik yang kredibel dalam mengendalikan konflik; peningkatan sumber daya manusia yang berkualitas; perluasan penerapan etika lingkungan; serta perkembangan asimilasi sosial budaya yang makin mantap sehingga lingkungan dapat memberikan kenyamanan dan keindahan dalam kehidupan. Selanjutnya, cara pandang terhadap lingkungan hidup yang berwawasan etika lingkungan perlu didorong melalui internalisasi ke dalam kegiatan produksi dan konsumsi, dengan cara menanamkan nilai dan etika lingkungan dalam kehidupan sehari-hari termasuk proses pembelajaran sosial, serta pendidikan formal pada semua jenjang atau tingkatan.

k. Meningkatkan kesadaran masyarakat untuk mencintai lingkungan hidup. Kebijakan itu diarahkan terutama bagi generasi muda sehingga tercipta sumber daya manusia yang berkualitas dan peduli terhadap isu sumber daya alam dan lingkungan hidup. Dengan 
DE IFGa Lata

Jurnal Ilmu Hukum

FAKULTAS HUKUM UMSU

demikian, pada masa yang akan datang mereka mampu berperan sebagai penggerak bagi penerapan konsep pem- bangunan berkelanjutan dalam kehidupan sehari-hari.

\section{KESIMPULAN DAN SARAN \\ Kesimpulan}

Campur tangan pemerintah daerah dalam pengelolaan lingkungan hidup di era otonomi daerah mutlak diperlukan, terutama melalui perumusan instrumen ekonomi dalam hukum lingkungan, dan hal ini merupakan amanah Pasal 42 dan Pasal 43 Undang-Undang No. 32 Tahun 2009, yang menentukan bahwa dalam rangka melestarikan fungsi lingkungan hidup, Pemerintah dan Pemerintah Daerah wajib mengembangkan dan menerapkan instrumen ekonomi lingkungan hidup, yang meliputi: (1) perencanaan pembangunan dan kegiatan ekonomi; (2) pendanaan lingkungan hidup; dan (3) insentif dan/atau disinsentif. Instrumen perencanaan pembangunan dan kegiatan ekonomi termasuk "internalisasi biaya lingkungan hidup". Selanjutnya dalam Penjelasan Pasal 43 Undang-Undang No. 32 Tahun 2009, disebutkan bahwa yang dimaksud dengan "internalisasi biaya lingkungan hidup" adalah memasukkan biaya pencemaran dan/atau kerusakan lingkungan hidup dalam perhitungan biaya produksi atau biaya suatu usaha dan/atau kegiatan.

Penetapan instrumen ekonomi yang terkait dengan internalisasi biaya lingkungan hidup sebagaimana yang tertuang dalam Pasal 42 jo. Pasal 43 Undang-Undang Nomor 32 Tahun 2009 sebenarnya merupakan upaya untuk menerapkan prinsip pencemar membayar dalam kaitannya dengan pemanfaatan atau pengelolaan lingkungan hidup yang berpotensi dapat menyebabkan terjadinya pencemaran dan/atau kerusakan fungsi lingkungan hidup. Prinsip pencemar membayar sesungguhnya merupakan prinsip pengalokasian biaya dari pengusaha atas potensi.

Pencemaran yang ditimbulkan, terutama dalam pemanfaatan lingkungan. Adapun alasan pembenar penerapan prinsip pencemar membayar melalui internalisasi biaya eksternal, karena biaya eksternal (negatif) pemanfaatan lingkungan untuk kegiatan ekonomi (faktor produksi), seharusnya tidak dibebankan kepada pihak yang tidak ikut menikmati keuntungan dari kegiatan usaha.

\section{Saran}

Pengusaha harus mengupayakan pendanaan secara internal dari setiap pengeluaran yang berdampak pada lingkungan (internalisasi biaya). Oleh sebab itu, penerapan prinsip internalisasi biaya lingkungan dapat dimaknai sebagai upaya memperhitungkan biaya-biaya yang harus ditanggung oleh pelaku kegiatan ekonomi akibat timbulnya kerugian lingkungan. Gagasan dasar dari prinsip ini adalah biaya lingkungan dan sosial, harus diintegrasikan ke dalam proses pengambilan keputusan yang berkaitan dengan penggunaan sumber-sumber daya alam tersebut (Muhammad Muhdar, 2009: 75).

Prinsip internalisasi biaya lingkungan mendasari materi muatan pembangunan berkelanjutan, dan pada hakikatnya bertujuan untuk menggugah kesadaran hukum pelaku ekonomi agar lebih kritis memperhitungkan dampak- dampak yang timbul akibat kegiatan ekonominya, dan dalam sudut pandang hukum, prinsip pencemar membayar harus dinormatifikasi melalui pengaturan yang jelas.

Beberapa aspek penting yang membutuhkan pengaturan terkait prinsip pencemar membayar adalah penegasannya sebagai prinsip pertanggungjawaban hukum dalam kasus- 
kasus lingkungan, terutama sengketa lingkungan dari apek hukum perdata. Sebagai bagian dari sistem hukum perdata, maka penentuan ganti kerugian pun seharusnya didasarkan tidak saja pada seberapa besar kerugian manusia tetapi mencakup nilai pada valuasi ekonomi lingkungan, sehingga yang diharapkan adalah bentuk perlindungan kepentingan manusia dan sekaligus melindungi kelestarian fungsi lingkungan hidup, demi kepentingan pada masa sekarang maupun masa depan. 
Jurnal Ilmu Hukum

FAKULTAS HUKUM UMSU

\section{DAFTAR PUSTAKA}

Easton, Thomas A. (Eds). (2008). Taking Sides: Clashing Views on Controversial Environmental Issues, McGraw Hill.

Huda, Ni'matul. (2007). Pengawasan Pusat Terhadap Daerah Dalam Penyelenggaraan Pemerintah Daerah, Yogyakarta: FH-UII Press.

Huda, Ni'matul. 2009. Hukum Pemerintahan Daerah. Bandung: Nusa Media

Indonesia. Bandung: Binacipta.

Irianto, Yoyon Bahtiar. Konsep dan Urgensi Pemberian Otonomi Pemerintahan Kepada Daerah. Universitas Pendidikan Indonesia, Bandung, t.t, 3.

Koesoemahatmadja. 1979. Pengantar ke Arah Sistem Pemerintahan Daerah di Indonesia. Bandung: Bina Cipta.

Muhdar, Muhammad. (2009). Eksistensi Polluter Pays Principle dalam Pengaturan Hukum Lingkungan di Indonesia. Mimbar Hukum, Volume 21, Nomor 1, 75.

Seokanto, Sorejono., \& Muji, Sri. (2003). Penelitian Hukum Normatif Suatu Tinjauan Singkat. Jakarta: Rajawali Pers.

Supriadi. 2008. Hukum Lingkungan di Indonesia: Sebuah Pengantar. Jakarta: Sinar Grafika.

Syafrudin, Ateng. (1983). Pasang Surut Otonomi Daerah. Bandung: Bina Cipta

Undang-Undang Nomor 17 Tahun 2007 Tentang Rencana Pembangunan Jangka Panjang Nasional Tahun 2005-2025.

Undang-Undang Nomor 32 Tahun 2009 tentang Perlindungan dan Pengelolaan Lingkungan Hidup.

Undang-Undang Nomor 32 Tahun 2004 tentang Pemerintahan Daerah.

World Commission on Environment and Development. (1987). Our Common Future, Oxford:

Oxford University Press. 